\title{
What's the use of a hashtag? A case study
}

What can a study of social media offer socio-legal studies? Although there are now sophisticated techniques for the analysis of social media, socio-legal studies has yet to draw on them fully. In this paper, we demonstrate how Twitter can produce insights about protest, law and legality. We do so through a case study method, using the so-called bedroom tax. We look at two different ways in which protest against the bedroom tax has been mobilised. The first method involved challenging a policy in the courts using a test case or cases. We discuss the litigation strategies and mess that they created. We counterpose those strategies against those of four prolific 'tweeps' who, using a traditional interview method, participated in our study. We argue that, despite the small number of participants, each of these people has in their own way been enormously influential and made things happen. Our position is not an evaluative one - of the different strategies (which, in any event, overlap) - but that legality is mobilised in different ways, different purposes, and our tweeps may well have been, in this case study, rather more successful in their challenges than the lawyers.

Key words: bedroom tax; social media; law and legality 
Empirical researchers now have an enormous variety of methods and texts for their study. However, the core argument in this paper is that social media offers a set of textual resources, which have been largely neglected by socio-legal scholars but which have significant purchase in thinking about the translations of legality in everyday life. If we socio-legal scholars claim to be interested in the mundane, the everyday, and in the different mechanisms through which protest is voiced and power comes to be exercised horizontally, then our argument is that we must take social media seriously. To put it another way, the simple hashtag can become a powerful tool in the sense that it gets things moving, often operating at the interstices between a tactic and a strategy. ${ }^{1}$ That is, perhaps nothing is intended by a 'post' of a 'microblog' but it reaches a potentially huge and diverse audience who might themselves make things move. ${ }^{2}$ In this sense, hand-held so-called smart telephones enable social media to become a powerful intermediary among other tools. ${ }^{3}$

To exemplify this argument, we use a case study of the bedroom tax, ${ }^{4}$ which we discuss in the first section. We look at two different ways in which protest against the bedroom tax has been mobilised in the following two sections. The first method is the now traditional method of challenging a policy in the courts using a test case or cases. ${ }^{5}$ We discuss the litigation strategies and mess that they created. The second method is through social media. Our social media of choice for this study is Twitter. ${ }^{6}$ But, as we make clear, ours is a study of legality. Social media offers not only a seemingly passive dataset, but it also has significant purchase in thinking about the translations of legality in everyday life. It may also provide textual resources to resist a narrative which 'reinforces the image of there being a clear-cut divide between two sets of values - those of private, individualistic selfinterest on the one hand, and those of public, collective interests on the other.'

While some use the words 'law' and 'legality' interchangeably, or as explanations of each other, ${ }^{8}$ we adopt the distinction drawn by Ewick and Silbey. On the one hand, we have formal law, which has

\footnotetext{
${ }^{1}$ In de Certeau's terms: The Practice of Everyday Life (1980), 36-7.

${ }^{2}$ If we are serious about 'reassembling the social', then, like Latour and others, we should be using and taking social media seriously: http://www.bruno-latour.fr/mixed_media

${ }^{3}$ So that 'when you hook up with this circulating entity, you are partially provided with consciousness, subjectivity, actoriality etc': B. Latour, 'On recalling ANT', in J. Law and J. Hassard (eds), Actor Network Theory and After (1999), 18.

${ }^{4}$ We discuss the label 'bedroom tax' below - our choice of this phrase to describe the rule is both political and because, as a result of the phenomena we are seeking to explain in this paper, namely social media, it has become instantly recognisable.

${ }^{5}$ H. Hodge, 'A test case strategy', in M. Partington \& J. Jowell (eds), Welfare Law and Policy (1979); T. Prosser, Test Cases for the Poor: Legal Techniques in the Politics of Social Welfare (1983); C. Harlow \& R. Rawlings, Pressure through Law (1992). We retain the scepticism that, when lawyers become involved, they tend to '... set about defining the "public interest" - and then think of the best way they can "satisfy" it. In other words, the limits of the so-called "public interest" come to correspond mysteriously with the ability of the profession to "serve" this "interest"': Z. Bankowski \& G. Mungham, Images of Law (1976), 53.

${ }^{6}$ We could just as easily have chosen Facebook, through which much of the popular protest was (and continues to be) organised. However, the fast-moving, short-form of Twitter provides a principal method of public popular protest against the bedroom tax as we discuss below.

${ }_{7}$ C. Barnett, 'Publics and markets: What's wrong with neoliberalism?', in S. Smith, R. Pain, S. Marston and J. Jones III (eds), The Sage Handbook of Social Geographies (2010) p 271.

${ }^{8}$ P. Bourdieu, 'The force of law' (1987) Hastings Law Journal 813, where the distinction is drawn between law and the juridical field; L. Fox O'Mahony, 'Property outsiders and the hidden politics of doctrinalism', (2014)
} 
its coupling with legal institutions; on the other hand, we have legality (or, rather, legalities), which '... refer to the meanings, sources of authority, and cultural practices that are commonly recognised as legal, regardless of who employs them or for what ends. In this rendering, people may invoke and enact legality in ways neither approved nor acknowledged by the law. ${ }^{9}$ We take this extension because the expanded version of legality allows what is screened out by the law to become visible; the law bottlenecks facts through its narrow head; but, when we start to think about legality (or legalities), other possibilities and strategies of resistance become possible.

There are now sophisticated qualitative and quantitative methods available to us for analysing tweets. ${ }^{10}$ However, we draw on a set of four qualitative interviews conducted with the people behind the tweets, in which we asked about their purposes and programmes for action. This method mirrors that used by Gerbaudo in a study of the use of social media in the 2011 Egyptian revolution, the indignados movement in Spain, and Occupy Wall Street. ${ }^{11}$ Gerbaudo's purpose was to provide a counter to the "unbounded techno-optimism of [some] social media theorists", on the one hand, as well as the techno-pessimism of other commentators through interviews with activists and observations of public gatherings. We discuss this literature around the use of social media for protest activity, developed in anthropological and communications studies, in the third substantive section of this article, before drilling down to our specific case study and noting its distinctiveness.

Our data offers a small sample, but it is a sample of the most prolific and political tweeters who were tweeting at that time (Summer, 2013) either solely or partly about the bedroom tax. Our point about this sample, though, is that despite its size, each of these people has in their own way been influential, as we discuss in the third section. If power is a mode through which an actor - a thing gets another actor - another thing - to act or omit to act, then these actors (the combination of human and social media) are potentially getting others to act. ${ }^{12}$ It is not our intention to offer an evaluation or comparison of these methods of mobilisation. Our suggestion is that we are able to draw attention to a series of narratives documenting how social media may occupy a lacuna created by the impossibility or implausibility of formal legal challenge to the reasonableness of central government policy that has been the subject of Parliamentary debate. Those narratives suggest that social media proved capable of supporting and perhaps even supplanting this court-based endeavour.

Current Legal Problems; B. Latour, An Inquiry into Modes of Existence: An Anthropology of the Moderns (2013), 359.

${ }^{9}$ P. Ewick and S. Silbey, The Common Place of Law: Stories from Everyday Life (1998), 22. This extended version of legality should be distinguished from the elision sought by Alan Hunt in his revision of his Foucault and the expulsion of law thesis: A. Hunt, 'Encounters with juridical assemblages: Reflections on Foucault, law, and the juridical', in B. Golder (ed), Re-reading Foucault: On Law, Power and Rights (2012). Hunt argues, at $\mathrm{p}$ 78 , that the "'legal" is characterized by its primary orientation to the making of, the content of, the interpretation and application of, and, in general, the priority accorded to, substantive rules'.

${ }^{10}$ For discussion, see S. Jeffares, Interpreting Hashtag Politics: Policy Ideas in an Era of Social Media (2014), ch 4; A. Wilkie, M. Michael and M. Plummer-Fernandez, 'Speculative method and twitter: Bots, energy and three conceptual characters' (2014) 63 Sociological Review 79; E. Yardley and D. Wilson, 'Making sense of "Facebook murder"? Social networking sites and contemporary homicide', (2015) 54(2) Howard Journal of Criminal Justice 109; T. Palmer, 'Talking the (slut)talk, walking the (slut)walk: Negotiating a global movement in a local context', unpublished paper on file with the author.

${ }^{11}$ P. Gerbaudo, Tweets and the Streets: Social Media and Contemporary Activism (2012).

${ }^{12}$ See for example, M. Foucault, 'Afterword: The subject and Power', in H. Dreyfuss and P. Rabinow, Michel Foucault: Beyond Structuralism and Hermeneutics (1983); B. Latour, Reassembling the Social (1996); E. Cloatre, Pills for the Poorest (2012). 


\section{The bedroom tax}

The bedroom tax forms part of a suite of social security reductions brought into effect during the Coalition government's austerity turn. ${ }^{13}$ It is a bright line rule which prescribes a percentage reduction in housing benefit for the under-occupation of a property in the social sector. ${ }^{14}$ If a property is under-occupied by one bedroom, housing benefit is reduced by 14 per cent; if it is underoccupied by two or more bedrooms, then housing benefit is reduced by 25 per cent. The regulations do not define bedroom, ${ }^{15}$ although they do define who is entitled to a bedroom. ${ }^{16}$ The regulations mirror those affecting the private rented sector, ${ }^{17}$ with one significant difference: they came into effect immediately. ${ }^{18}$ Whereas the private rented regulations only came into effect on a new claim to housing benefit, the social sector regulations came into effect immediately (although there was a period between its announcement and coming into effect). ${ }^{19}$

That was (and is) the formal law - the bright line rule inscribed by Statutory Instrument - but it was encrusted with justifications which, superficially, appeared plausible. As we discuss below, appeals to fairness provide the basis for the Department for Work and Pensions' cultural schema about the bedroom tax. A simplistic binary (fair/unfair) provided the vehicle through which the policy was conveyed to the public.

Two rationales were provided for the policy. ${ }^{20}$ First, too many households were under-occupying social housing so that best use was not being made of the stock. The purpose then was to provide a financial incentive to move - although, that 'incentive' was effective coercion because of the inevitable rent arrears (and probably undefendable possession proceedings) that would follow from the reduction. As Gibb notes, this rationale 'stretches credibility compared with the simple sense that it is about cutting [housing benefit]' because '... it is a remarkably poorly targeted underoccupation policy and that critically behavioural assumption that people will down-size ... are not

\footnotetext{
${ }^{13}$ Others included the benefit cap, cuts to council tax allowance, and rises by CPI as opposed to RPI - see, further, K. Gibb, 'The multiple policy failures of the UK bedroom tax' (2015) International Journal of Housing Policy forthcoming. For a critique, see 'Social policy in an age of austerity' (2012) 32 Critical Social Policy Special Issue.

${ }^{14}$ It is contained in the Housing Benefit (Amendment) Regulations 2012, SI 2012/3040 Reg 5; which inserted two new regulations into the Housing Benefit Regulations $2006^{14}-$ Reg A13 and Reg B13.

${ }^{15}$ This came later in a DWP Circular HB/U6 2013, which suggested that '... the only consideration should be the composition of the household and the number of bedrooms as designated by the landlord, but not by measuring rooms', para 4. Provided a room was large enough to accommodate a single bed, it was to be regarded as a bedroom (para 5); see also Circular HB/U6 2014, and the critique:

http://nearlylegal.co.uk/blog/2014/12/not-quite-minister/.

${ }^{16}$ Reg B13(5). This was amended to include limited provision for foster carers (but not prospective adopter parents), members of the armed forces on operations, and a child who could not share a bedroom for medical reasons: Housing Benefit (Amendment) Regulations 2013 SI 2013/665; Housing Benefit and Universal Credit (Size Criteria) (Miscellaneous Amendments) Regulations, SI 2013/2828.

${ }^{17}$ Housing Benefit Regulations 2006, Reg 13D

${ }^{18}$ There was, however, one (further) element of farce to these regulations. It became apparent that those households who had been in consistent receipt of housing benefit from 1996 or earlier were not affected by the bedroom tax. When this became known to the DWP, they closed down this 'loophole. The full story can be found at http://nearlylegal.co.uk/blog/2014/01/bedroom-tax-pre-1996-claims-exemption/; http://nearlylegal.co.uk/blog/2014/01/bedroom-tax-the-effect-of-the-pre-1996-claim-exemption/.

${ }^{19}$ The policy was announced in June 2010 and came into force in April 2013.

${ }^{20}$ These were provided in interviews to the media, for example on $1^{\text {st }}$ April 2013, when the bedroom tax came into force: BBC News, “lain Duncan Smith: Reforms 'make work pay'”, http://www.bbc.co.uk/news/uk21993453.
} 
borne out. Indeed smaller properties in the market sector may induce higher [housing benefit] costs than larger social rented properties'. ${ }^{21}$

Secondly, it was said to be unfair that people in the private rented sector were unable to underoccupy, whereas people in the social sector could do so (although nothing was said about owneroccupiers who under-occupy). This provides a superficially compelling example of the current politics of austerity, which as Clarke and Newman describe, 'combines an economic logic with a particular moral appeal (to shared sacrifice and suffering, to fairness and freedom, to a sense of collective obligation)'.22 This rationale suggests something that private landlords have been arguing for some time - a level playing field between social and private renting. Indeed, the policy could plausibly be presented as a coerced exit, a type of quasi-privatisation, in the sense that households, faced with unaffordable social housing and nowhere to move within that sector, would see the private rented sector as the only alternative. ${ }^{23}$

In any event, perhaps the real motivating factor was the need to find savings in the huge housing benefit black hole. When the Coalition came to power, the housing benefit bill was around $f 21$ billion. There was limited slack left to reduce the bill in the private rented sector - a consequence of the policy shift to market rent from 1989 - and, in any event, it was well-known that occupiers with some degree of reliance on housing benefit are discriminated against by private landlords. The social sector was a target, in particular because a high proportion of occupiers were reliant on housing benefit. ${ }^{24}$ Further, the Coalition, in a quite remarkable volte face were making sweeping changes to what they referred to as 'lifetime tenancies', in part to secure mobility within the social sector and between social and private sectors. ${ }^{25}$ Against the $f 21$ billion housing benefit bill, the bedroom tax was thought originally to save around $£ 480$ million and around $£ 930$ million over two financial years. ${ }^{26}$ Professor Becky Tunstall obtained the DWP's modelling through a freedom of information request (although these contained no formulae) and found that, using real data provided by four large housing associations, the projected savings were unlikely to be achieved. ${ }^{27}$ Further, there was some evidence that the policy acted to shunt costs from the DWP to local authorities and other housing providers. ${ }^{28}$

\footnotetext{
${ }^{21}$ K. Gibb, 'The multiple policy failures of the UK bedroom tax' (2015) International Journal of Housing Policy forthcoming, 14.

22 J. Clarke \& J. Newman, 'The alchemy of austerity' (2012) 32 Critical Social Policy 299, 309.

${ }^{23}$ The data from the DWP's study suggests that, where statistics were available, only a small proportion of affected households did move to the private rented sector (DWP, Evaluation of Removal of the Spare Room Subsidy, (2015), p 53) - but our point is that it provided a push-factor, not that it succeeded in so pushing.

${ }^{24}$ The impact assessment assumed a figure of around 63 per cent, taken from the English Housing Survey.

${ }^{25}$ DCLG, Local Decisions: A Fairer Future for Social Housing, Consultation (2010); Localism Act 2011; for a critique, see H. Carr, D. Cowan, \& C. Hunter, Tenure Rights and Responsibilities (2010) http://www.jrf.org.uk/sites/files/irf/tenure-rights-responsibilities-full.pdf

${ }^{26}$ DWP, Housing Benefit: Size Criteria for People Renting in the Social Sector (2012); cf S. Wilcox \& J. Perry, UK Housing review 2014 (2014), where the saving is reduced to $£ 330$ million. Duncan-Smith, however, suggested that the bedroom tax had saved $f 1$ billion: R. Prince, 'lain Duncan Smith: government's controversial bedroom tax has saved taxpayers $f 1$ billion' Daily Telegraph, 21 March 2105. The official statistics can be found at https://www.gov.uk/government/statistics/number-of-housing-benefit-claimants-and-average-weekly-spareroom-subsidy-amount-withdrawal.

${ }^{27}$ This was because the DWP modelling was based on underestimates of tenant activity in response to the bedroom tax: B. Tunstall, Testing DWP's Assessment of the Impact of the Social Rented Sector Size Criterion on Housing Benefit Costs and other Factors (2013).

${ }^{28}$ House of Commons Work and Pensions Committee, Support for Housing Costs in the Reformed Welfare System, Fourth report of Session 2013-4, HC 720 (2014), paras 84-8.
} 
The iniquity in the policy reflected the fact that it affected households which were allocated a longterm social tenancy of a social property from which they would have to move on the basis that they now could not afford it. Many allocation schemes had previously actively encouraged underoccupation so that households could grow into a property, particularly in hard-to-let areas. ${ }^{29}$ The balance of housing supply in many areas affected, however, meant that they were unable to move (even if they had wanted to do so). ${ }^{30}$ Secondly, the impact assessment originally suggested that 660,000 households would be affected (about 31 per cent of all working age housing benefit claimants living in social housing). ${ }^{31}$ Of that total figure, it was estimated that 420,000 had some form of a disability, so that the policy clearly targeted such households.

What became apparent quickly was that the notion of a 'spare' bedroom for a considerable proportion of such households was a complete nonsense - such rooms were being used to store vital equipment, or where partners were unable to sleep together, or the room was simply too small. Thirdly, it was always accepted that the policy would have regional effects - the highest affected households lived in Welsh social housing (46 per cent) and the lowest in South West England social housing (20 per cent) - and those effects would be sensitive to supply:demand of social housing, so that rural areas would be particularly affected. ${ }^{32}$ Fourthly, it was said that those affected, including households with a disabled person, would be entitled to make a claim for a discretionary housing payment, ${ }^{33}$ but these payments were (at least at one time) thought to be short-term and, in any event, were discretionary and payable from a locally administered capped fund (so, once the fund was exhausted, there could be no more payments). ${ }^{34}$ The government allocated an increasing amount of money to such payments ( $£ 165$ million in 2014-5), ${ }^{35}$ and some local authorities added to it from their housing revenue accounts, ${ }^{36}$ although it is now reducing.

When the government finally published the interim report of the evaluation of the policy, it was not surprising that just 4.5 per cent of affected households had downsized within the social sector and 1.5 per cent had moved to the private rented sector; 59 per cent of affected households were in rent arrears and there was widespread concern that households were being forced to make cuts to household essentials (food, heating, etc) and incurring other debts to pay the rent. Because the bedroom eligibility related to children's ages, some households were simply waiting for their child to reach the next age up. ${ }^{37}$ The final report, ${ }^{38}$ slipped out just before the seasonal holiday at the end of

\footnotetext{
${ }^{29}$ See, for example, the discussion in A. Marsh et al, Piloting Choice-Based Lettings: An Evaluation (2003).

${ }^{30}$ For example, it was suggested that it would take between three and ten years for under-occupying households to down-size: K. Gibb, The Bedroom Tax in Scotland (2013).

${ }^{31}$ DWP, Housing Benefit: Size Criteria for People Renting in the Social Sector (2012), para 22. The figure was subsequently down-sized itself to 547,342 and then 522,342 . It has been noted that the problem with this impact assessment was that '....analysis is unavoidably static and cannot take account of wider economic change. Further, available analysis tends to focus on the big picture - rarely does it consider variety in local housing market contexts': K. Gibb, C. Leishman, G. Young \& A. O'Sullivan, The Impact of the Housing Benefit Reforms on the Social rented Sector: A Study for the Northern Ireland Housing Executive (2013).

${ }^{32}$ Id, para 34.

33 Discretionary Financial Assistance Regulations 2001/ 1167; DWP, Discretionary Housing Payments Manual, April 2013 (2013).

${ }^{34}$ These problems with the discretionary housing payments system were what persuaded the Court of Appeal, in part, to hold that the private rented regulations were unlawful: Burnip v Birmingham CC, Trengove $v$ Walsall MBC, and Gorry v Wiltshire CC [2012] EWCA Civ 629, [45]-[47].

${ }^{35}$ Housing Benefit Circular S1/2013, Circular S1/2014.

${ }^{36}$ W. Wilson, Housing Benefit: Discretionary Housing Payments, House of Commons Library SN/SP6899 (2014), 3.

${ }^{37}$ CCHPR, Evaluation of Removal of the Spare Room Subsidy, Research Report No 882, Interim Report (2014).

${ }^{38}$ DWP, Evaluation of Removal of the Spare Room Subsidy (2015).
} 
2015 along with a number of other announcements and reports prejudicial to the government's various positions, ${ }^{39}$ generally confirmed these interim findings, adding that many affected households were cutting back on household essentials (food, clothing and energy/utility bills) and non-essentials; and, further, the quantitative evidence of those affected suggested that up to 80 per cent ran out of money before the end of the week/month. ${ }^{40}$

In an epilogue to the reprinted edition of their book, The Blunders of our Governments, King and Crewe suggest that the bedroom tax was a blunder, as they define it: 'On the face of it, it would seem to be a straightforward case of cultural disconnect, with ministers and officials having little or no idea what practical effects their measure would have on those affected by it'. ${ }^{41}$ For Gibb, there are multiple policy failures. What binds the two analyses together is a realisation that the projected savings to housing benefit were unlikely to materialise. ${ }^{42}$

These sober analyses, however, do not reflect the degree of hardship suffered by households as a result of the bedroom tax. Suicide attempts in housing and job centre offices were reported. ${ }^{43}$ Social landlords' business planning was affected. Indeed, some social landlords sought to use the inherent flexibility in the regulation around the definition of 'bedroom' by re-defining the number of bedrooms in their properties so as to assist their occupiers. ${ }^{44}$ There was an episode in which the UN's official rapporteur on adequate housing, Raquel Rolnick, recommended that the bedroom tax be suspended immediately and fully re-evaluated. Her report contained the following comment about the bedroom tax:

In only a few months of its implementation the serious impacts on very vulnerable people have already been felt and the fear of future impacts are a source of great stress and anxiety.

Of the many testimonies I have heard, let me say that I have been deeply touched by persons with physical and mental disabilities who have felt targeted instead of protected; of the grandmothers who are carers of their children and grandchildren but are now feeling they are forced to move away from their life-long homes due to a spare bedroom or to run the risk of facing arrears; of the single parents who will not have space for their children when they come to visit; of the many people who are increasingly having to choose between food and paying the penalty. Those who are impacted by this policy were not necessarily the

\footnotetext{
${ }^{39}$ A. Sparrow, 'Taking out the trash: How spin doctors wrangle the news', The Guardian, $17^{\text {th }}$ December 2015, http://www.theguardian.com/politics/2015/dec/17/taking-out-the-trash-how-spin-doctors-wrangle-the-news. ${ }^{40}$ Leading Baroness Lister to respond to Lord Freud that 'I think we read different reports', in the House of Lords debate on the final report.

${ }^{41}$ A. King \& I. Crewe, The Blunders of our Governments, Reprinted (2014), 427.

${ }^{42}$ See notes 21 and 37 above.

${ }^{43}$ L. Clark, 'Horror at "bedroom tax" suicide bid', the Courier.co.uk, 30 ${ }^{\text {th }}$ August 2013, http://www.thecourier.co.uk/news/local/fife/horror-at-bedroom-tax-suicide-bid-1.125447; O. Clay, 'Man cuts throat with knife in bedroom tax protest', Liverpool Echo, $26^{\text {th }}$ July 2013 , http://www.liverpoolecho.co.uk/news/liverpool-news/man-cuts-throat-knife-runcorn-5327123; K. Mudie \& N. Nelson, ‘Bedroom tax victim commits suicide: Grandmother Stephanie Bottrill blames government in tragic note', Daily Mirror, $12^{\text {th }}$ May 2013, http://www.mirror.co.uk/news/uk-news/suicide-bedroom-tax-victimstephanie-1883600\#.UY88S_pPnNM.twitter

${ }^{44}$ Lord Freud, the welfare minister, however, caused the death-knell of this attempt to circumvent the policy in a letter to social landlords. He wrote: '...we would expect the designation of a property to be consistent for both Housing Benefit and rent purposes. Blanket redesignations without a clear and justifiable reason, and without reductions in rent, are inappropriate and do not fall within the spirit of the policy'. Further, 'Where it is found that a local authority has re-designated properties without reasonable grounds and without reducing rents, my Department would consider either restricting or not paying their Housing Benefit subsidy'.
} 
most vulnerable a few months ago, but they were on the margins, facing fragility and housing stress, with little extra income to respond to this situation and already barely coping with their expenses. ${ }^{45}$

The Tories, of course, pilloried her (and it is significant that Rolnick is a 'her': 'a woman from Brazil', as Shapps described her, ${ }^{46}$ and complained of her bias and that her report was an 'absolute disgrace' in a letter to the $\mathrm{UN}^{47}$ ); and the Tory press added the epithet 'loony' and 'loopy', even stooping to describe her as a 'dabbler in witchcraft who offered an animal sacrifice to Marx'. ${ }^{48}$

\section{Legal challenge}

There are two elements to this section. The first relates to the judicial reviews of the bedroom tax. The second relates to the 'jurisprudence' as it developed in the First Tier Tribunal. Here, the oddest things occurred and outcomes varied widely. Here, until recently, we entered into the land of Brobdingnag. ${ }^{49}$ What binds these together in our analysis, though, is that - whether they like it or not - they are bound by the law. Whether they be cause lawyers, politically active or otherwise, judges or advocates, the arguments discussed in this section are forced in to the law bottleneck; they cannot be outside the law. They may see themselves as being up against the law but the law engulfs them and, win or lose, triumphs (to adapt the well-known expression 'I fought the law and the law won')..$^{50}$

\section{Judicial reviews ${ }^{51}$}

As regards these challenges, which have hitherto been largely unsuccessful, our argument (which is hardly novel to socio-legal scholars) is that judicial review has the effect of bottlenecking the stories of the applicants and making them irrelevant. ${ }^{52}$ Thus, in the leading case on the social sector bedroom tax, MA v Secretary of State for Work and Pensions, the facts of the 10 cases are relegated to an Appendix to the judgment, which is much more concerned with the policy process on which there is a splurge of information. ${ }^{53}$ In all but one case, the claimants contended that they needed an extra bedroom because another member of the household (child, adult child or partner) was disabled. In the other case, the claimant suffered from obsessive compulsive disorder; he had filled two rooms with papers and contended that he could not move to smaller accommodation. The only time these facts get prayed in aid of the judgment is to demonstrate that the regulations plainly

\footnotetext{
${ }^{45}$ http://www.ohchr.org/EN/NewsEvents/Pages/DisplayNews.aspx?NewsID=13706\&LangID=E.

46 https://redbrickblog.wordpress.com/2013/09/11/a-woman-from-brazil/.

47 http://m.bbc.co.uk/news/uk-politics-24046094.

48 http://www.channel4.com/news/bedroom-tax-un-grant-shapps-brazil-row;

http://www.dailymail.co.uk/news/article-2418204/Raquel-Rolnik-A-dabbler-witchcraft-offered-animalsacrifice-Marx.html.

${ }^{49}$ That is, an enormous space but the maps to get there are contradictory.

${ }^{50}$ Bourdieu, op cit n 9; Bankowski \& Mungham, op cit n 6.

${ }^{51}$ These cases have largely been dealt with in an excellent way by Neville Harris, in his excellent 'Welfare reform and the shifting threshold of support for disabled people', (2014) 77 Modern Law Review 888, 920-5. This section is designed simply to add further observations.

52 In a related context, Lord Neuberger said, '...save in the most exceptional circumstances, it would be wrong in principle to have any regard to the housing circumstances and requirements of an individual applicant when considering the validity of a housing allocation scheme under Part 6 of the 1996 Act; R(Ahmad) Newham LBC [2009] UKHL 14, [60].

${ }^{53}$ Cf Burnip v Birmingham CC, Trengove v Walsall MBC, and Gorry v Wiltshire CC [2012] EWCA Civ 629.
} 
discriminate against the claimants under Article 14, Schedule 1, Human Rights Act $1998 .{ }^{54}$ But that is a throwaway point because it is so clear (despite the Secretary of State's argument to the contrary).

Similarly in the case of whether a claimant occupying a three bedroom property, one bedroom of which was a sanctuary because of domestic violence, it was put as follows:

As I have observed, the Sanctuary Scheme is obviously a good thing, both in the case of A and in the case of others who have endured domestic violence. The evidence I have about this applicant suggests that she is a deserving recipient of the benefits that scheme can bring, and common sense suggests that it would be best for everyone if she were able to stay in her current property. It has been her home for 25 years, and has been adapted to provide her with the security she deserves. There are also the points which can be made about the uncertainty of future funding and the effect of that on someone in the position of A. I do not underestimate that matter. As I say, it seems to me that the benefits of a Sanctuary Scheme go well beyond the physical security offered by adapting a property. For A it has brought the security of knowing that she can stay where she is, with her support network around her. The loss of that certainty is not a good thing.

But whilst these factors and the human effect of all this on $A$ and those like her weighs in the balance, the question I have to determine is not simply whether it would be a good idea to put A's home in jeopardy. It is whether the Defendant's decision to adopt this policy (or to implement it in this way) is manifestly without reasonable foundation. ${ }^{55}$

Our supplementary argument is that government is a learning organisation. It learnt from its unsuccessful defence to the private rented sector regulations, and, with these cases, it provided the court with a welter of information about the policy process. We learn, for example, how the government considered making an exception for disabled persons living in adapted accommodation, but decided against doing so.

From August 2011 onwards, there was a consistent view within Government that the most workable solution to the difficulties for the disabled that would result from the introduction of the bedroom criteria was to increase what could be made available through DHPs. In a paper dated 2 September, the officials provided more information on the expected response to an increase in the DHP package as the best means of mitigating the effect of the underoccupation measure for 'hard cases' such as people living in adapted accommodation. Para 4 of the paper stated that those living in adapted accommodation had been singled out by the 'lobby' as a group that should be exempted from the measure (mostly) on cost grounds. The officials stated that they had explored the possibility of an exemption for this group and other types of 'hard cases' which had been flagged up by stakeholders. They had concluded that trying to define 'significantly adapted accommodation' for exemption purposes would not be workable. Such an exemption would be difficult and expensive to deliver effectively, especially when Universal Credit was introduced. It would either be too broad brush or leave out many other equally deserving hard cases. ${ }^{56}$

\footnotetext{
${ }^{54}$ [39].

${ }^{55}$ [2015] EWHC 159 (Admin), [62]-[63].

${ }^{56} \mathrm{MA}$, [11].
} 
The Court of Appeal found that it was open to the Secretary of State not to legislate for an imprecise class of persons to whom the criteria would not apply. In essence, this would produce too much uncertainty and complexity in the system. ${ }^{57}$

Given that the question was whether or not the regulations were 'manifestly without reasonable foundation', ${ }^{58}$ the DWP was always going to get over this low obstacle with that extra information. Mere disagreement is not sufficient to meet the threshold; nor are reasonable grounds for criticism; nor that the line has been drawn imperfectly. ${ }^{59}$ Added in to the mix that the regulations had been discussed by Parliament, and, in particular, 'some of the alleged shortcomings in the scheme that have been canvassed before us were debated in Parliament', the Court was even less likely to find them unlawful on the grounds of discrimination. ${ }^{60}$

However, all of this left the DWP with another problem. The reason why they were successful in the main has been the existence of the discretionary housing payments scheme. This underlined their success in MA and the subsequent cases, Rutherford $v$ Secretary of State for Work and Pensions and $A R v$ Secretary of State for Work and Pensions. ${ }^{61}$ In MA, Lord Dyson MR said, 'In combination, [Duncan Smith's] reasons are far from irrational. Central to his thinking is the idea that there are certain groups of persons whose needs for assistance with payment of their rent are better dealt with by DHPs than $\mathrm{HB}^{\prime}{ }^{62}$

Much of the discussion at first instance in Rutherford concerned essentially the academic nature of the question. That is, the Rutherfords had been guaranteed DHP from the commencement date through to April 2015. The child was to turn 16 in October 2015. Pembrokeshire had effectively undertaken to consider whether to extend the DHP in this case and Stuart-Smith J suggested that 'it would appear perverse for Pembrokeshire to reach a contrary decision in the future if the scheme and the Claimants' circumstances remain unchanged'. ${ }^{63}$ The DHP award had 'plugged the gap', and, although DHPs were discretionary, the local authority was obliged to exercise its discretion in accordance with public law principles and human rights legislation. One consequence of this is that the legal challenges have now morphed in to challenges against local authority discretionary housing payments policies. ${ }^{64}$

\footnotetext{
${ }^{57}$ The Court was able to distinguish Burnip because (at [64]) Burnip was concerned with a different scheme; DHP had changed and been increased; the evolution of the policy many not have been before the court in Burnip; and the Regulations that were being considered in Burnip were not made under the shadow of the financial crisis and the need to reduce public spending which the Coalition Government was elected in 2010 to bring about.

${ }^{58}$ This was because the discrimination was indirect, in the Thlimennos sense; although it was said that the test was the same whatever the discrimination in the context of benefits: Humphreys v Revenue and Customs

Commissioners [2012] UKSC 18, [2012] 1 WLR 1545, Baroness Hale(which appeared after Burnip and possibly is one reason why the outcomes between the cases were different).

${ }^{59} R$ (RJM) v Secretary of State for Work and Pensions [2009] AC 311, [57], Lord Neuberger. As Lord Dyson MR put it in $M A$, at [80], 'The stringent nature of the test requires the court to be satisfied that there is a serious flaw in the scheme which produces an unreasonable discriminatory effect'.

${ }^{60}$ Bank Mellat v HM Treasury [2013] 3 WLR 179, [44], Lord Sumption; Black v Wilkinson [2013] EWCA Civ 820, [2013] 1 WLR 2490, [46]-[49].

${ }^{61}$ Respectively [2014] EWHC 1613 (Admin); [2015] EWHC 159.

62 [82].

63 [53]; thus effectively binding the council to pay DHP until that time.

${ }^{64}$ See, for example, $R$ (Gargett) v Lambeth LBC [2008] EWCA Civ 1450; R(Winder) v Sandwell MBC [2014] EWHC 2617 (Admin); R(Hardy) v Sandwell MBC [2015] EWHC 890.
} 
When the cases reached the Court of Appeal, both Rutherford and $A$ were successful. ${ }^{65}$ The Court distinguished MA on the basis that these two cases raised specific, discernible and certain categories with limited numbers (particularly sanctuary schemes). ${ }^{66}$ The actual facts of the cases were again irrelevant - the real issue was whether DHPs saved the scheme and whether MA was distinguishable on the facts. It was held that they did not in these limited cases. In Rutherford, the Secretary of State had got himself in a twist effectively. He argued that an extra bedroom is required for the carer of a disabled adult but not for the carer of a disabled child because the latter would be cared for by family members. That did not wash with the Court, which exposed the problematic reasoning in the following way:

[T] he Secretary of State did not address how the distinction could be justified by reference to the best interests of a child as a primary consideration. He justified the distinction between making provision for a bedroom for disabled children but not for disabled adults by reference to the best interests of the child and explained the different treatment on that basis. On that basis, it seems to us very difficult to justify the treatment within the same regulation of carers for disabled children and disabled adults, where precisely the opposite result is achieved; provision for the carers of disabled adults but not for the carers of disabled children. In this context, moreover, the argument based on the promotion of independent living for adults, whereas children can be cared for within the family, has little purchase.

The outcome of this Court of Appeal decision, then, can be presented as a triumph of liberal law and reason. Liberal law, in its objectivity and technical garb, has beaten the DWP. ${ }^{67}$ However, it can equally be seen as an extremely limited break on the policy and, of course, the bedroom tax remains for the significant majority of those others affected. The limits of law here must be acknowledged, particularly as regards benefits - court reverses of policy are regularly simply overturned by further regulations in a "cat and mouse" game. ${ }^{68}$ Further, the distinction between these cases and MA is rather harder to fathom. Simply because these cases were specific and small in number made the challenges successful, so that the broader bedroom tax policy wasn't threatened; because MA involved a more generic challenge to the policy, it was unsuccessful. Such distinctions are what give liberal law its life blood but look like a method of avoiding the significant questions about the effects of the bedroom tax on households - a luxury enjoyed by the senior courts.

\section{Into Brobdingnag ${ }^{69}$}

Two themes emerged in the bedroom tax decisions before the First Tier tribunal ('FTT'): (a) what is a 'bedroom'? and (b) when can MA be distinguished?

As regards the first question, some wild and wacky arguments were put to (and accepted by) the FTT which suggests that the proper test can be derived from the overcrowding provisions in the Housing Act 1985 (specifically sections 324-6), the Housing Health and Safety Rating System in the Housing

\footnotetext{
65 [2016] EWCA Civ 29.

66 "MA makes a clear distinction between a broad class for which DHPs are appropriate, and a narrow class for which DHPs are not appropriate. The case of A is within the narrow class covered by the decision in Burnip", [53].

${ }^{67}$ See, for example, P. Butler, "Appeal court rules bedroom tax discriminatory in two cases", The Guardian, $27^{\text {th }}$ January 2016.

${ }^{68}$ D. Cowan, Housing Law and Policy (2011), ch 8.

${ }^{69}$ Ordinarily, of course, the decisions discussed in this section would not be available. However, they can be found at http://nearlylegal.co.uk/blog/bedroom-tax-ftt-decisions/.
} 
Act 2004, and, perhaps most interesting, drawing on dicta of Lord Bingham in Uratemp Ventures $v$ Collins. $^{70}$

In SC231/13/01993 and SC236/13/0942, Judge Moss' position was that those arguments were essentially addressing other issues and were outside the context of the bedroom tax. The latter was a question of fact, not law. It is an ordinary English word. The question was one of both objective and subjective criteria, of course decided at the date of the decision (but the actual room use at the date of the decision is not determinative - her point was that this is not a once and for all decision as individual circumstances change). Objectively, would that room normally be classed as a bedroom? Subjectively, are there any particularly circumstances which would suggest that a room normally considered a bedroom should not be one? Further, a bedroom had to be considered in the light of 'home' (in respect of which benefit is payable ${ }^{71}$ ). Home connoted a degree of privacy and sanctuary, personal space as well as being somewhere to sleep.

Thus, in SC236/13/0942, it became apparent after a home visit that the room classed as a bedroom actually had a lift going in to it and required sufficient space for a wheelchair etc. A bed could just about have been squeezed in to the room but there would have been no privacy or sanctuary: 'It is the need for the use of the lift which takes this room out of the definition of a bedroom in a home'.

Much of the nonsense has been put to rest by the Upper Tribunal decision in SSWP v Nelson and Fife Council. ${ }^{72}$ This draws attention to '...a number of case sensitive factors will need to be considered including (a) size, configuration and overall dimensions, (b) access, (c) natural and electric lighting, (d) ventilation, and (e) privacy'. ${ }^{73}$ Room sizes for overcrowding rules are irrelevant, however.

On the second question, distinguishing MA and Rutherford, perhaps the most remarkable FTT decision was in the case of Carmichael. Mr and Mrs Carmichael's case had been considered explicitly in $M A$, in which the Court of Appeal made clear that their case was caught by the regulations. However, when the case was remitted to the FTT, it found in favour of the Carmichaels on the ground that they were discriminated against. ${ }^{74}$ The basis for this decision was that, while $M A$ was a judicial review of the scheme, this was a statutory appeal of an individual decision. Oddly, Judge Watson said that he did not find $M A$ '... particularly helpful in dealing with the case'. ${ }^{75}$ In other cases, the FTT has distinguished MA and Rutherford where DHP has not 'plugged the gap', a position which seems the logical outcome of the DWP's position. ${ }^{76}$

\section{Bedroom tax and the uses of twitter}

In this section, our discussion is preceded by a review of the literature on social media, social movements, and protest. We then provide a short description of twitter for the uninitiated, following which we move to our case study. We draw attention to the development of the label 'bedroom tax', and argue that Twitter was the space where the label became solidified, or perhaps

\footnotetext{
${ }^{70}$ [2001] UKHL 43, in which Lord Bingham said that the use of the room was to be judged at the date on which the decision was made.

${ }^{71}$ S. 130 SSCBA 1992.

72 [2014] UKUT 525 (AAC)

73 [31]

${ }^{74}$ SC068/13/12054, Tribunal Judge Watson; see also the decision of Judge McMahon in SC068/14/01608.

${ }^{75}$ Para 15.

${ }^{76} \mathrm{Mr}$ Gresham's case, SC008/13/08128, in which the court expressed scepticism about the lawfulness of the local authority's DHP policy.
} 
better 'stablilised', ${ }^{77}$ as representing the benefit reduction, despite other attempts (on Twitter and other spaces) to produce different labels. We then draw attention to our four interview participants' involvement. To protect their anonymity, we have used sobriquets as descriptors: 'the smiling assassin'; 'the understater'; 'the legal conduit'; 'the social media polymath' (who was also involved in a bedroom tax challenge).

During 2014, we conducted telephone interviews with them, deciding on that method so that their anonymity could be protected (in three cases, the twitter name was not the real name of the research participant - however, in two such cases, there are links to their blogs which contain details about them). Only one of the participants was known to us prior to the study. Between the four of them, they had over 16,000 followers and had tweeted over 85,000 times. $^{78}$ The interviews lasted between 40 minutes to an hour and a half. Obviously, this is an exploratory study and we can do no more than draw some basic, limited messages from our data.

The key point is that, despite only a limited sample, Twitter has the potential to work alongside other strategies and tactics to flatten structures of power so that four, relatively ordinary individuals, who feel passionately about the bedroom tax, can affect our understandings as well as get people to do things; ${ }^{79}$ or to put it another way, they open up fields of knowledge and action. ${ }^{80}$ We are not suggesting in any sense that these four have somehow changed the world of the bedroom tax, which remains in place in any event, but as four ordinary people with a social media computer programme on their smartphones, they have considerable power. It is fair and right to say that they are all male, so that this flattening of power in this case study is only partial. ${ }^{81}$

We are also interested in the ways in which legality is enfolded in to their actions. As they tweet, we argue that they are (consciously and/or unconsciously) producing legality. The names we have given them (which are not artificially constructed labels, but phrases they used in their interviews, and have been agreed with them) and their practices are imbued with legalism, as we discuss below.

\section{Social media, social movements and protest}

There is little doubt that, since 2009 at the latest, social media has become intertwined with social movements and protest. In 2009, it was reported that 'There may have been few things that protesters, politicians and activists share, but during the G20 meeting, they were united by their use of Twitter ${ }^{82}$ One of the key questions now addressed in the literature is not whether social media is

\footnotetext{
${ }^{77}$ See E. Cloatre, Pills for the Poorest (2013), 14: 'the "translation" of multiple connections into a new actor with a sense or appearance of stability is at the core of much [ANT] research'.

${ }^{78}$ As at $13^{\text {th }}$ April 2015.

${ }^{79}$ Cf the critique of the \#bringbackourgirls as hashtag politics: http://jeffar.es/2014/05/11/subterraneanhashtag-blues/

${ }^{80}$ M. Foucault, 'Afterword: The subject and power', in H. Dreyfuss \& P. Rabinow, Michel Foucault: Beyond Structuralism and Hermeneutics (1982), 221. As he puts it earlier, in discussing antiauthority oppositions, 'They are an opposition to the effects of power which are linked with knowledge, competence, and qualification: struggles against the privileges of knowledge. But they are also an opposition against secrecy, deformation, and mystifying representations imposed on people'.

${ }^{81}$ It is important to make this point in the context of the more general issue about the 'trolling' of female tweeps.

${ }^{82}$ M. Ward, 'Twitter on the front line', BBC News, $2^{\text {nd }}$ April 2009:

http://news.bbc.co.uk/1/hi/technology/7979378.stm
} 
related to social movements and protest action, but how it does so and under what conditions it relates to them. ${ }^{83}$

On the one hand, there are those who regard the capacities of social media, particularly twitter, to produce networked populations, with decentralised and horizontal power structures, which facilitated the development of new forms of activism. ${ }^{84}$ The so-called 'Arab Spring' uprisings and Occupy movements are often held up as examples of this technological development. ${ }^{85}$ On the other hand, there are those who have expressed concerns at the development of new methods of controlling dissenting populations, but, more pertinent to this article, that it develops what has become known as 'slacktivism' - activism with minimal personal effort (such as clicking 'like' to a post) that has no social or political impact. ${ }^{86}$

These polarised positions have given rise to a third set of literatures, which have provided more nuanced positions. Juris, for example, a student of Castells (the doyen of the network analysis), has argued that the widespread use of social media by activists has created a "logic of aggregation," which involves the assembling of masses of individuals from diverse backgrounds within physical spaces'; further, it offers 'an alternative cultural framework that is shaped by our interactions with social media and generates particular patterns of social and political interaction that involve the viral flow of information and subsequent aggregations of large numbers of individuals in concrete physical spaces' ${ }^{\prime 87}$ Gerbaudo's analysis also fits in to this more patchwork theoretical framework. His use of the term choreography, as a writing of movement or action, particularly resonates with this study; but his study also stresses the significance of participants' emotional investment in protest, which potentially breaks down, or works with, the individualisation inherent in the consumption of social media. ${ }^{88}$

What binds these studies of social movements together is their relationship with forms of protest that are combined with some physical co-location of populations. Hence, these studies emphasise the ways in which physical space becomes entangled with virtual space. What is distinctive about our study is its engagement with modern forms of legality, itself an individualising set of narratives which does not require physical spaces per se. ${ }^{89}$ Nevertheless, the kinds of discussions above prompt us (again) that we should not over-claim for the use of twitter as well as providing a useful vocabulary for discussing protest.

\section{Twitter: A note for the uninitiated}

\footnotetext{
${ }^{83}$ See, for example, S. Valenzuela, 'Unpacking the use of social media for protest behaviour: The roles of information, opinion expression, and activism', (2013) 57(2) American Behavioral Scientist 920, 921.

${ }^{84}$ Most notably here is the network analysis developed by Manuel Castells in his trilogy, the last of which, Networks of Outrage and Hope: Social Movements in the Internet Age (2012).

${ }^{85}$ Cf M. Lim, 'Clicks, cabs, and coffee houses: Social media and oppositional movements in Egypt, 2004-11' (2012) 62(2) Journal of Communication 231, which provides a corrective to this analysis, arguing that, seen over a longer time frame as well as activist strategies. The argument there is that 'social media represent tools and spaces in which various communication networks that make up social movement emerge, connect, collapse, and expand' (at p 234).

${ }^{86}$ The term derives from E. Morozov, The Net Delusion: The Dark Side of Internet Freedom (2011).

87 J. Juris, 'Reflections on \#Occupy Everywhere: Social media, public space, and emerging logics of aggregation', (2011) 39(2) American Ethnologist 259, 260 and 266; it is important to Juris' position that these logics of aggregation exist alongside the networking logics - thus, he refers to the generation of 'crowds of individuals'. ${ }^{88}$ Gerbaudo, op cit n 12 , ch 2.

${ }^{89} \mathrm{Cf}$ the kinds of housing protests discussed by D. Cowan and S. Wheeler, 'The reach of human rights', in T. Xu and J. Allain (eds), Property and Human Rights in a Global Context (2015).
} 
A tweet is a form of micro-blog posted on the host site, Twitter. It is made up of 140 characters (including spaces etc), and sometimes known as a 'microblog' (a particularly useful label, as a tweet might link to other social media outlets, such as blogs). It is posted by an individual or organisation (sometimes known as a 'tweep') with an address beginning with the @ symbol. One's 'followers' (ie those people who press a button on Twitter to follow you) then receive the micro-blog. In turn, those followers may 'retweet' or 'modify and retweet', ${ }^{90}$ so that a micro-blog has the potential to reach an unlimited number of followers. Similarly, one can reply to a tweet (although a quirk of Twitter is that a reply can only be seen by those who follow both parties if a full stop or something else is put at the start of the reply) and 'favourite' a tweet (which essentially just saves it to your account).

Tweets range from the mundane (food, train journeys etc) to the commercial (advertising) to the political to the abusive (known as 'trolls'). They provide a valuable, if occasionally limited, source of information about specialist subject areas. The hashtag is used in a tweet to denote a subjectmatter, an event (such as a conference), or sometimes simply for amusement. It enables people, not just one's followers, to follow a theme which can be searched and saved. So, for example, the hashtag \#UKhousing might be used by a tweep to follow and/or join a debate on that subject.

Key to its significance is that the twitter programme is available not just on a desktop computer but loaded (often preloaded) on to smartphones and tablets, with an email alert when a person tweets at you, retweets or replies to you or favourites a tweet you have written. It is an easy-access, readily available programme on which random thoughts and considered opinions are posted. Apparently, there are 974 million existing twitter accounts, although a considerable proportion are inactive. ${ }^{91}$ Celebrities have millions of followers and, no doubt, armies of tweeters on their behalf. ${ }^{92}$ Grant Shapps, the current Conservative Party Chairman, who plays a central role (as Housing Minister) in the case study in this paper, was said to have found a way to increase his followers to over $55,000 .{ }^{93}$ As Jeffares asks rhetorically, 'what proportion of think tanks, columnists, politicians, senior civil servants, journalists, newspapers, media organisations, social scientists, bloggers, researchers, lobbyists and consultants are not on twitter?'. ${ }^{94}$

\section{Labelling}

The battle of the bedroom tax was as much a battle of the label as it was over policy. ${ }^{95}$ In Gerbaudo's terms, there were a multiplicity of choreographers initiating and guiding the label, but its production as the 'bedroom tax' allowed for 'the symbolic condensation of people around a common identity and their material precipitation in public space' ${ }^{96}$

\footnotetext{
${ }^{90}$ This practice is commonly preceded by ' $\mathrm{RT}$ ' and ' $\mathrm{MT}$ '.

${ }^{91}$ E. Sherman, 'Many twitter users don't tweet, finds report', CBS Moneywatch, 14 April 2014, http://www.cbsnews.com/news/many-twitter-users-dont-tweet-finds-report/

${ }^{92} \mathrm{See}$, for example, http://twopcharts.com/twoplist. One of us, after tweeting that they had been out on a \#JLS dinner, found that they were followed (and then unfollowed) by numerous fans of the pop group, JLS.

93 P. Wintour, 'The rise and fall of Grant Shapps' twitter followers', The Guardian, $7^{\text {th }}$ September 2012, http://www.theguardian.com/politics/2012/sep/07/grant-shapps-twitter-followers-analysis. Shapps' activities on Twitter have been 'storified' - a programme which pulls together various tweets commonly with a hashtag - at https://storify.com/anyapalmer/grant-shapps. Shapps currently has 84.4 thousand followers.

${ }^{94}$ See S. Jeffares, Interpreting Hashtag Politics: Policy Ideas in an Era of Social Media (2014), p 6.

95 A. Marsh, 'The battle over the "bedroom tax": Politics, rationality and discourse', paper presented to the European Network of Housing Research Conference, 2014.

${ }^{96}$ Op cit $n$ 11, 44.
} 
The regulations, themselves, describe the rules as the 'Maximum rent (Social Sector)'. Originally, the DWP termed them fairly neutrally as the 'social sector size criteria', but this quickly morphed in to 'under-occupation of social housing'. ${ }^{97}$ That had provided one of the rationales for the policy in the label and effectively advanced the fairness rationale. The 'bedroom tax' label appears to have begun in a speech given by the crossbench peer, ${ }^{98}$ Lord Best, who has been a well-known figure in UK housing for nearly 50 years. From his point of view, it was a tax because occupiers had nowhere to move to and they had to pay a levy to the Exchequer. His point was that everybody was suffering tenants and housing providers - and this was fundamentally unfair. As Marsh acknowledges, the 'tax' label 'is a fairly familiar tactic in British political debate, because we know it can work to undermine a policy', viz. the poll tax, pasty tax, caravan tax; although the bedroom tax is not a tax in and of itself, but a reduction in personal subsidy. ${ }^{99}$ And, of course, the tax label has particular emotional connotations, providing an impetus during a period of initiation of protest and an attraction to gatherings during the phase of sustainment. ${ }^{100}$

The DWP has referred to the policy as the 'spare room subsidy'. Its reasons for so doing are clear, in that it seeks to neutralise the unfairness of a tax on bedrooms by reference to the idea of a subsidy for spare rooms as an appeal to a common sense proposition about the unfairness of that spare $\mathrm{room} / \mathrm{s}$ (in the social sector, at any rate). Indeed, all documentation about the bedroom tax produced by the DWP now uses this label and has done since $27^{\text {th }}$ February $2013 .{ }^{101} \mathrm{In}$ fact, Grant Shapps appears to have been the progenitor of this label, having tweeted that he would be appearing on a Radio 4 programme to debate the 'spare room subsidy'. ${ }^{102}$ But, by this stage, the bedroom tax label had stuck. ${ }^{103}$ Indeed, in a memorable moment of Parliamentary irony on $24^{\text {th }}$ October 2013, Lord Freud, the welfare minister, criticised the 'bedroom tax' label, but then went on to use it himself. ${ }^{104}$

Whether or not the Labour party had adopted the 'bedroom tax' label, common usage was clearly established by early 2013. Jeffares conducted an analysis of tweets posted over 72 hours between $8-11^{\text {th }}$ April 2013 where the terms bedroom tax, \#bedroomtax, spare room subsidy and \#spareroomsubsidy were used. Of a total of 8,155 tweets, which he estimated as being approximately 80 per cent of Twitter traffic, 7,936 used either 'bedroom tax' or \#bedroomtax (this

\footnotetext{
${ }^{97}$ Exemplified in the impact assessment title.

${ }^{98}$ This, in turn, echoed the National Housing Federation's position (of which Best was a long-time chair): Jeffares, 2014, 129.

${ }^{99}$ We are, of course, in danger of dancing on the head of a pin here. If one considers the housing benefit part of a claimant's property, as the new property thesis might do, then a reduction in amount operates as a tax. There is also a pragmatic reason for the 'tax' label - it simply uses fewer of the available 140 characters in a tweet.

${ }^{100}$ Gerbaudo, op cit n 12, 44.

101 Paul Lewis Money, 'DWP FOI on first use of phrase "spare room subsidy", http://paullewismoney.blogspot.co.uk/2014/06/foi-response-on-use-of-phrase-spare.html. This terms appears to have superseded the label 'under-occupation penalty'.

102 Tweet, $17^{\text {th }}$ February 2013; see Jules Birch, 'Welfare, the bedroom tax and the battle of language', https://julesbirch.wordpress.com/2013/08/02/welfare-the-bedroom-tax-and-the-battle-of-language/. ${ }^{103}$ Indeed, Duncan-Smith made a formal complaint against the BBC of bias because of their use of the 'bedroom tax' label: A. Glennie, 'Duncan Smith blasts BBC for "bedroom tax" bias; Work and Pensions Secretary accuses corporation of promoting Labour's views in furious letter', Daily Mail, $28^{\text {th }}$ October 2013.

${ }^{104}$ N. Nelson, 'Lord Freud says bedroom tax term is misleading ... then refers to it as bedroom tax himself', Sunday People, $27^{\text {th }}$ October 2013.
} 
included re-tweets or quoted tweets). ${ }^{105}$ This suggests a particular moment when the harnessing of social media (alongside other sources) produced the label.

\section{Strategising social media: Protest and legality}

In combination, our four research participants, using different strategies of everyday life, have had considerable effects in structuring the fields of action. However, for the purposes of this analysis we group them into two predominant strategies. The first are two information providers (the Understater and the Legal Conduit); the second are challengers (the Smiling Assassin and the Social Media Polymath). Both sets of strategies used twitter for legal effects. This is particularly the case in respect of the challengers, who were the most vocal forms of legal protester (albeit in different ways), seeking to operate against the law. That is, they sought to use the formal law against itself, and twitter was used to distribute a 'how to' set of knowledges. However, the information providers mobilised their information tactically, providing explicit or implicit instructions to others to challenge the policy. ${ }^{106}$ We might see them as gaming the law, showing its fissures and cracks. However, it is important that our organising trope here is no more and no less than that, ie a method of organising our data. As Ewick and Silbey themselves suggest, '... a person may express, through words or actions, a multifaceted and possibly contradictory consciousness'. ${ }^{107}$ Further, they themselves are simply labels, conveyances of meaning (like the bedroom tax label itself), which are overly simplistic, and overly structured, so we must recognise that our participants' narratives do not easily shoehorn in to these categories.

\section{The information providers}

In two cases, the Understater and the legal conduit, the provision of information was essentially the anti-authority challenge. Apparently neutral information could be tweeted to significant effect; knowledge could be used to challenge apparently authoritative accounts of the bedroom tax by a single tweet. The Understater ${ }^{108}$ tweeted about welfare reform generally and focused mostly on the provision of formal media reports which he trawled ('it has become part of my job'). He became involved in Twitter '... as an opportunity to try to effect change and to push out the message that I wanted to get out there. For this specific purpose, my frustration was that central government rhetoric about welfare recipients and negative stereotyping did not correspond with my day-to-day experience'. ${ }^{109}$ His passion was social justice and he communicated that emotion through the understatement of tweets - sometimes just with a headline and a weblink to a local newspaper ('grabbed' by a web-based sorting agent), adding in the local MP's twitter address so that the MP saw it. He sought to be balanced about the bedroom tax in his tweets, suggesting that 'some campaigners are their own worst enemy'. He had written a piece on Facebook about the bedroom tax which had 80,000 'shares'. His strategy was to give a tweet a visual look, through the use of returns, include specific MPs in his local tweets, and amplify a headline in a tweet. He told us that he was 'compelled to do it; it's within me; if I don't push back on what I see as anti-evidential words and phrases coming out of central government then I can't stop myself. Some things come out and I grab my phone to tweet something about it'. As he put it, 'retweeting is always nice when it goes a bit crazy'.

The Legal Conduit came to the bedroom tax in part in response to his followers and, in part, because people began to send him their FTT judgments. Recognising that these were not readily available (as

\footnotetext{
105 129-30.

${ }^{106}$ See J. Lemert, Does Mass Communication Change Public Opinion after all? (1981); Valenzuela, op cit n 89.

107 At p. 50.

${ }^{108}$ So-called because, as he said, 'understatement is the most powerful thing on twitter'.

${ }^{109}$ The understater is a housing professional.
} 
they are unpublished) but that they might be useful as a legal resource for others, including but not limited to his followers, he blogged about them and tweeted the blog. Twitter was, in this sense, a way to publicise his blog (which is read over 35,000 times per month) ${ }^{110}$ and the judgments ('I wasn't expecting them to be quite that barking ... You expect a certain degree of reasoning from a [FTT] but I wasn't expecting the disparity, possibly on some issues, but not on the generality'). However, he also saw himself as being the 'pessimistic voice of legal reason' against other apparently authoritative, positive tweep voices. The Legal Conduit is very aware that his blog and Twitter account are followed by judges and the DWP (which apparently was circulating his notes).

Although it may seem easier to say that the Legal Conduit's approach was 'legal' - indeed, like the lawyers striving to beat law through law, he was simply providing information about law - but we like to think that his was a rather more subversive use of legality than a simplistic and superficial label conveys. He recognised (and was theoretically adept enough to recognise) that information about law can make things happen. He was not looking for clients, but offering a service, demonstrating where the potential fault lines in law lay. He was both inside and outside law in that sense. The Understater, though, was also agitating for legal change. His apparently neutral approach belied a clear political (in a narrow sense) goal - a hope that through the provision of information, politicians would see sense - and he adopted an 'effects of the law' approach to obtain that legal change.

Neither of these tweeps could be regarded as 'slacktivists' (although a retweet could be regarded as an example of slacktivism). They were professionals with a significant following, whose dissemination of mobilising information to that following was a recognition of the values and uses of information in both online and offline participation. ${ }^{111}$ They were both informal 'leaders' (although neither would style themselves like that), using twitter to open different windows on the protest space; or to use a different metaphor, choreographing different spaces. ${ }^{112}$ Certainly, the Legal Conduit was seeking to provide an alternative perspective about the prospects of success of challenging a bedroom tax determination through particular sets of arguments, and publicising the judgments of the FTT supporting or dismissing those arguments. The Understater was seeking to change political thought, or at least the image of the recipient of state support for housing, his tweets predominantly reflecting his passionate belief in social justice and the appalling presentation of such recipients by some politicians and right wing print and other media (including tweeps).

\section{The challengers}

The challengers were both active, albeit in different ways, in challenging the bedroom tax. The Smiling Assassin's strategy was to destroy the bedroom tax from within, principally by using techniques of administrative justice, ${ }^{113}$ and creating a model letter requesting extensive further information of the housing benefit authority, such as for policies regarding the definition of a 'bedroom'. The purpose of that letter was as much to highlight the inadequacies of the law's failure

\footnotetext{
${ }^{110}$ He told us that a single tweet leads to over 200 new visits to his blog.

${ }^{111}$ Valenzuela, op cit $\mathrm{n} 89,925$.

${ }^{112}$ As Segerberg and Bennett put it, 'Twitter is interesting as an organizing mechanism within the specific protest ecology. As well as transmitting information, networked protest spaces constitute negotiated spheres of individual and collective agency. As digital and social media become increasingly prominent, they too become networking agents ... within the protest space': A. Segerberg \& W. Bennett, 'Social media and the organization of collective action: Using twitter to explore the ecologies of two climate change protests', (2011) 14(3) The Communication Review 197, 201.

${ }^{113}$ See, for example, R. Thomas, 'Administrative justice, better decisions, and organisational learning', [2015] PL 111.
} 
to define what constitutes a 'bedroom' in law as it was to put a spanner in the bureaucracy administering the benefit. For, rather than legal challenges, the Smiling Assassin had a strategy. It was to 'swamp' housing benefit offices with review requests and appeals against bedroom tax assessments; he highlighted dreadful practices of social landlords and local housing benefit offices; he praised 'good' practices (such as some landlords decisions to re-classify properties as having less bedrooms, although this negatively affected their income stream).

He developed a model housing benefit review letter which those affected could modify and send out. The strategy was to defeat the money-saving logic of the bedroom tax through reviews and appeals, with which he also assisted. In the first three weeks of it appearing, the Smiling Assassin told us that his model letter had been downloaded 180,000 times. As he put it:

If every tenant affected by the bedroom tax decision appealed then the system is brought to its knees. The government expects just $3 \%$ to appeal and estimates an appeal costs the local council $£ 200$. It won't and it will cost the council $£ 1500$ for everyone that appeals and about f18m to $[X]$ Council if all 12,000 appeal.

Such was the significance of this letter that the Chartered Institute of Housing, the professional body of housing providers, issued statements decrying the strategy, while at the same time saying that they were working behind the scenes to disrupt the iniquitous tax. The Smiling Assassin was clearly interested in law, in the sense that he would assist people appearing in the FTT, but, as he put it, 'courts don't dispense justice'. His legal strategy was, in part, that he 'just need[ed] one judge to say it's ultra vires just to accept the view of landlords [ie the landlord designation of a room as a bedroom] without the authority checking. It would all become unworkable'. Social media, and particularly the link between Twitter and his blog, became his dissemination tools because 'social media mobilises tenants but also the dissemination of shite. Lots of what I do is dispelling myths, plus points and negative points'.

The Social Media Polymath was a little different from the others in this sample. He was a social tenant who was affected by the bedroom tax and who had challenged it. He was ill and his partner disabled, so that their 'spare room' was full of medical treatment equipment. He was also a campaigner. His tweeting had, in part, opened his profile up and he had become quite prominent: 'Twitter has proved to be a very good way of getting our story out as it has developed. ... Following our story going out there was an avalanche almost of other people tweeting about their case'. His strategy was simple - 'to get people to think about the truth rather than rhetoric'. His strategy had been successful, and his political and media profile was developing in diverse, almost uncontrollable ways. He described his court appearance as a sort of 'DWP, tory, IDS bullshitfest really'. We discussed whether the outcome of his case had reflected how he himself had felt about his position, and whether, in effect, the law had represented him. His view was that his barrister, who was incredibly busy, had done a good job but he wished that he could have had an hour to explain his case to the barrister. Thus, the legal process had effectively silenced him, whereas his other strategies were enabling him to tell his story publicly.

As Ewick and Silbey observe, legality is polyvocal and, although one can distinguish different strands of legality in their different approaches, they are enmeshed together. The Smiling Assassin was seeking to smash the system from within, but he was at that time equally willing to bow before the law in his desire to get one judge to say the bedroom tax was ultra vires, even though (to him) courts don't dispense the law. The same type of complex, contradictory narrative appears in the Social 
Media Polymath's narrative - he actively used the law for his own individual gain but at the same time decried its utility, preferring to focus on a political campaign. ${ }^{114}$

In these strategies, we can see the ways in which twitter and other social media formed part of broader choreographed narratives, designed either to smash the system and/or to force political change through drawing attention to the general and case specific iniquities of the tax. Like the Legal Conduit, twitter was used as part of a broader social and general media strategy by the challengers. They have affinities with Juris' logic of aggregation, because they were responsible for drawing together protestors at different points. In our appreciation, such a logic of aggregation can equally be the diffusion of the key messages to other physical or virtual spaces, and actants - the aggregation, for example, of the review letters, and the physical appearance of the characters at protest rallies or public debates.

\section{Conclusions: The bedroom tax and Twitter}

The denigration of the social security state by the Coalition government has been one of the defining features of austerity politics. In many respects, the bedroom tax is the apotheosis of that denigration, producing states of insecurity for people who can ill-afford that insecurity. The failure of the judicial reviews did, of course, produce one concession - that without discretionary housing payments, the policy potentially would have been in contravention of Article 14 discrimination. However, this concession is entirely in accordance with DWP policy. It enables them to say that the bedroom tax has reduced housing benefit expenditure, while at the same time requiring those affected to be reliant on the cash-limited, locally distributed, discretionary payment. For a while, the FTT operated as some sort of break on the policy in individual cases, albeit for very odd reasons. However, that now appears as an aberration, more than anything else.

Our argument in this paper, however, is both broader and simple. Twitter is a potentially fantastic resource for socio-legal researchers. It has been under-used. Because it is so fast-moving, one can find the stabilisation of a particular idea, the tipping point. It is used by the powerful for sure, and much Twitter-traffic is dull, but it can also be used to challenge policy and practice. The lifetime of a policy idea can now be very short. As Jeffares argues, 'Hashtag politics is a practice of modern policy-making where policy ideas are coined, fostered and imbued with meaning and associations, before eventually being overlooked, forgotten and seldom mentioned again' ${ }^{115}$

Our participants offered two different ways of using Twitter for a purpose - by providing information, to arm their followers and other recipients with information to challenge dominant or apparently authoritative narratives. We would stress the ordinariness of our research sample - with no disrespect to them, who probably have no other aspirations - but their reach is of significance; indeed, we selected them for our study precisely because of their choreographic positionality. Thus, the promise of social media is that potentially it adds to the available techniques that flatten power

\footnotetext{
${ }^{114}$ We see the secondary data analysed by S. Halliday and B. Morgan - "'I fought the law and the law won? Legal consciousness and the critical imagination', (2013) 66(1) Current Legal Problems 1 - as essentially making the same point about polyvocality - while they acknowledge and accept the limits of totalizing schemes and accept that 'much will be found in the spaces between the ends of the dimensional spectrums', they argue that these discourses are theoretically productive. ${ }^{115}$ P 145.
} 
structures and spatial imaginations. This is spatial governmentality in action; it is uncontrollable, miasmic, and enables actors to jump spatial scales. ${ }^{116}$

If socio-legal scholars are interested in the interstices between agency and structure, in understanding strategies of resistance, as well as the mundane (which we take to be three of the most significant sites of study), they should similarly be interested in following the Twitter actor flows. If we do so, and make that our starting point, we may end up with a rather different set of understandings of legality and legal spaces. ${ }^{117}$ In this way, through our data, we have sought to develop an analysis of legality and protest, demonstrating how social media may offer quite interesting challenges to our appreciations of that literature.

The social media literature review offered in this paper also provides interesting sparks for sociolegal researchers, interested in the uses of, as well as controls in, virtual and public spaces. We have been drawn particularly to the helpful analogy of choreography in this paper, as each of our participants was, in one way or another, seeking to choreograph aspects of protest against the bedroom tax. However, this literature also reminds us (if we needed reminding) of the limits of social media, and of the ways in which we interact both with it and beyond it. We should be careful not to essentialise social media, just as we should be careful to emphasise the limits of our data.

One particular limit of our study is that, while we can claim that our participants got things moving, we cannot claim a specific impact of their work beyond the attempt by the Smiling Assassin to bring down the decision-making bureaucracy. It may be that many of those others are 'slacktivists', but it is also clear that targeted information provision, publicisation of other social media (like blogs), alongside other strategies might make a difference. We cannot claim that twitter on its own provides the single successful protest resource; that would be a nonsense. However, it does proide a relatively new method of co-ordinating and developing a protest dance (to continue the choreographic metaphor). The bedroom tax still exists and is being propped up by the discretionary housing payments system. The voices of protest remain on twitter and elsewhere in the blogging and political communities, and new calls for its abolition are made. Yet, the response to the final research report by Lord Freud in the House of Lords was that the report demonstrated that 'the policy is promoting more effective use of housing stock and encouraging people to enter work and increase their earnings. We will therefore be maintaining the policy and will continue to protect vulnerable claimants who require additional support through discretionary housing payments'. ${ }^{118}$

There are other ways in which a study of social media might give added value, for example by thinking about the use of social media in reference to understandings of legal consciousness. Implicitly, we have drawn on that literature in this article. This point is, perhaps obvious. Legality is produced socially through twitter as it is through traditional media or in other places, like queues. Nevertheless, even though it may be a theoretically obvious point to make - that twitter is a site of

\footnotetext{
${ }^{116}$ See, for example, A. Akinwumi, 'Powers of reach: Legal mobilization in a post-apartheid redress campaign', (2012) Social and Legal Studies 1.

117 The perhaps counter-intuitive sociology of the door-closer by 'Jim Johnson', aka Bruno Latour, (in 'Mixing humans and nonhumans together: The sociology of a door-closer', (1988) 35(3) Social Problems 298) suggests some interesting narratives which might be developed here, particularly about human's lack of control of technology.

${ }^{118}$ House of Lords, 22 December 2015, col 2441, http://www.publications.parliament.uk/pa/ld201516/ldhansrd/text/151222-0001.htm
} 
legal consciousness - our relatively simple point is that this fact has been overlooked by the sociolegal community. ${ }^{119}$

In so doing, we have succumbed to the temptation to see legality everywhere - but, as Mezey suggests, ${ }^{120}$ if the law is everywhere so much that it is nowhere, how can we speak to data which is apparently extra-legal? So, for example, the Understater would not describe his role or perception as 'legal', but we have interpreted his data through that lens. That may be because of the totalising discourses of legality, the fact that our primary discipline is law and we consequently 'see' legality as being all around us; ${ }^{121}$ and/or the instrumental fact that this paper is designed in part as a socio-legal reflection on legality. It may also be a consequence of what Cotterell regarded as the meaninglessness of the inside-outside demarcation between law and sociology. ${ }^{122}$ However, in drawing on the breadth of the idea of legality, we have also demonstrated the ways in which our social media users sought to challenge the right of the law to provide the official account of their lived realities.

\footnotetext{
${ }^{119}$ See the interesting analysis in B. Morgan and D. Kuch, 'Radical transactionalism: Legal consciousness, diverse economies, and the sharing economy', (2015) 42(4) JLS 556.

${ }^{120}$ N. Mezey, 'Out of the ordinary: Law, power, culture, and the commonplace', (2001) 26(1) Law and Social Inquiry 145; see also K. Levine and V. Mellema, 'Strategizing the street: How law matters in the lives of women in the street-level drug economy', (2001) 26(1) Law and Social Inquiry 169; D. Cowan and D. Wincott, 'Exploring the legal', in D. Cowan and D. Wincott (eds), Exploring the Legal, Basingstoke: Palgrave.

${ }^{121}$ For discussion on the almost inevitable subjectivity in interpreting data, see A. Sarat, 'Off to meet the wizard: Validity and reliability in the search for a post-empiricist sociology of law', (1990) 15(1) Law and Social Inquiry 155.

${ }^{122}$ R. Cotterell, 'Why must legal ideas be interpreted sociologically?', 1998) 25(2) Journal of Law and Society 171.
} 